\title{
Rethinking Democracy: Mexico in Historical Perspective
}

\author{
DIANE E. DAVIS
}

New School for Social Research

VIVIANE BRACHET-MÁRQUEZ

El Colegio de Mexico

Since Robert Dahl's seminal writings on democracy more than two decades ago, interest in the topic has emerged again, especially among scholars analyzing democratic transitions. Great strides have been made in revealing the uncertain nature of these transitions (O'Donnell et al. 1986; Malloy and Seligson 1987; Diamond, Linz, and Lipset 1989; Hakim and Lowenthal 1991; O'Donnell 1994), in methodologically analyzing them as contested and "crafted" rather than spontaneous (Di Palma 1990), and in documenting the class and social forces that make democratic outcomes more likely (Rueschemeyer, Stephens, and Stephens 1992; see also Moore 1966). Despite these advances, there has been little change in our theoretical understanding of democracy. As Bruce Cumings has perceptively noted, recent studies of democratic transition have "given way to atheoretical and idiosyncratic explanations of more or less successful democratic 'openings" " in which little time is spent elaborating "the decision rule for saying this person is hard-line or softline, that system is 'liberalized autocracy' instead of 'limited democracy,'" or for defining democracy itself. If scholars do bring theory into their writings "through the back door of the obscure but telling footnote," he observes, "rather than advancing their own conception of democracy, [they] uniformly define democracy by reference to Robert Dahl's Polyarchy, a classic pluralist account of the North American system" (Cumings 1989:15-17).

A problem with Dahl's view of democracy is his conceptualization that governmental responsiveness to citizens' demands is built into periodically held electoral contests guaranteed by juridically protected individual rights

Research for this essay was partially supported by the United Institute of Peace and Petroleos Mexicanos. The arguments presented are the combined result of bibliographical research on the process of democratization and the following publications: Viviane Brachet-Márquez, The Dynamics of Domination: State, Class and Social Reform in Mexico (1910-1990) (Pittsburgh: University of Pittsburgh Press, 1994) and Diane E. Davis, Urban Leviathan: Mexico City in the Twentieth Century, Temple University Press, 1994. We would like to thank our anonymous reviewers for their comments, and Robert A. Alford for his careful substantive and stylistic editing of the whole manuscript.

0010-4175/97/1415-0546 \$7.50 +.10 @ 1997 Society for Comparative Study of Society and History 
(Dahl 1971:1). This approach leaves little room for analyzing cases that in today's world represent the most difficult challenges for genuine democratization: On one hand, exclusionary democracies in which many citizens' policy preferences remain unheeded by elected representatives, and on the other, inclusionary authoritarian regimes in which democracy is thwarted by the existence of authoritarian ways of responding to citizens' demands. Far from being blocked in these regimes, participation and contestation-the definitional foundation of democracy for Dahl—may in fact be encouraged, but in ways that fail to meet Western liberal requisites. Both problems underscore the limits of pluralist paradigms and invite further examination of cases deviating from definitional orthodoxy as a strategy to rethink theories of democracy.

\section{Seeking an Alternative Framework}

In this essay we focus on Mexico, a self-proclaimed one-party democracy whose existence poses a challenge to basic assumptions of the pluralist model. To make theoretical sense of the Mexican experience, especially its past and present difficulties in achieving democracy, we propose a framework for assessing democratic potential which builds on some of Dahl's original ideas about the relationship between participation, contestation, and democracy but moves considerably beyond.

First, ours is a broader conception of contestation and participation. In particular, we seek evidence of citizens' participation and contestation in activities and political institutions other than elections. This contrasts with Dahl, whose almost exclusive focus on elections eschews any conception of the political process that implies direct citizens' intervention in governmental affairs. We define participation as the institutional opportunities for the formal exercise of citizenship (such as participating in official party structures or voting). ${ }^{1}$ Contestation denotes the system's relative openness to the expression of political preferences both within and outside of the institutional limits set by past practices and the constitution (e.g. demonstrating, campaigning or voting for opposition parties, denouncing governmental policies, etc.).

Second, we analytically distinguish the different components of the democratic process. Rather than taking a strictly dahlian view of citizenship rights as the indissoluble combination of contestatory and participatory politics, we examine these dimensions separately and in relation to a third measure, government policy response, which we call accommodation. Accommodation is defined as the extent of governmental responsiveness to social, political and

\footnotetext{
1 Political participation in authorized opposition parties in Mexico, although formally legal, should in fact be regarded as evidence of contestation rather than participation, given the systematic repression of opposition party leaders and militants and their limited impact on national policymaking. Moreover, much of the increase in opposition party participation can be seen as evidence of accommodation, since the ruling party generally makes changes in opposition party registration and electoral law in response to societal contestation.
} 
economic demands generated through participation and contestation at a particular moment. Accommodation can come in the form of social and economic policies or as institutional reform. In contrast to Dahl, then, who did not measure governmental responsiveness separately because he saw it as as built into competitive politics and intrinsic to periodic electoral contests, we look for direct evidence of accommodation, conceptualizing it as the contingent outcome of interaction between citizens and state regarding specific issues or decisions.

Third, we view these three dimensions as contingently related to the interaction over time between two domains, namely, state and society. That is, we incorporate the analytic turn to civil society evident in the recent literature on democratization but absent in many older pluralist studies, without coupling this new emphasis with an analytic disregard for the state.

With this more broadly cast theoretical framework we look for evidence of - and obstacles to-democracy in the sequencing and cumulative historical experience of participation, contestation, and accommodation in both state and society, not in the mere presence or absence of any or all of these factors. ${ }^{2}$ We argue that Mexico's difficulties in achieving full democracy can be traced to the state's attempts, during critical historical junctures and over time, to absorb popular pressures through the accommodation of contestants' demands or their political incorporation into official party structures. These strategies initially quiet political mobilization but fuel the next contestatory cycle. The state responds again to demands and once again reshapes participatory structures. Contestation, participation, and governmental responsiveness thus occur independently of competitive elections; and this ongoing historical process keeps full democracy at bay.

\section{Why Mexico? Assessing Changing Definitions}

Mexico is an important case not just because it departs from Dahl's classic polyarchy in theoretically provocative ways but also because there is so little consensus on its democratic character, although the nature of its political institutions has been thoroughly analyzed (as in Padgett 1966; González Casanova 1970; Cosio Villegas 1973; Kaufman 1975; Reyna and Weinert 1977; Hamilton 1982; Smith 1991; Centeno 1994 and others). In the 1960s many

2 This is a more microanalytical view of historical paths to democracy which is bound to reveal far more complex patterns of political change than the three broad paths Dahl envisaged. Based on his diagram representing contestation vertically and participation horizontally, Dahl distinguishes three itineraries to democracy: the first goes from closed hegemony to oligarchy (i.e., contestation but no participatory inclusiveness), representing the English model; the second goes from closed hegemony to participatory inclusiveness but low contestation, representing the Prussian model; the third goes directly from closed hegemony to polyarchy, and represents the French model. The latter illustrates well the oversimplification in these historical trajectories. Although France did undergo a radical transition in 1791, it zigzagged several times between closed or semi-open hegemony in the course of the nineteenth century, finally settling down in polyarchy barely on the eve of World War I, and even after that suffering a major reversal from 1941 to 1945. 
scholars saw Mexico as one of the few quasi-democratic countries in Latin America (Scott 1964, Cumberland 1968, Padgett 1966 and Huntington 1968.). ${ }^{3}$ The absence of an independent and threatening military, the regularity of elections, and the orderly process of presidential succession spurred many theorists to regard Mexico as a model for its southern neighbors battling with military coups, widespread domestic opposition, ongoing violence, and electoral instability. The non-democratic features of one-party rule were overlooked in view of some political outcomes generally associated with democracy, such as political stability and civilian government.

This attitude held true not only for North American scholars comfortable with modernization theory (Cline 1962; Padgett 1966; Scott 1964; Huntington 1968) but also for Mexicans critical of modernization, like Pablo González Casanova (1970), who, despite warning of the dangers of presidentialism and patron-clientelism, argued that democracy, in Mexico and elsewhere, should be gauged by the ways in which decisions are made rather than by the presence of competitive parties. In short, for most scholars in the late 1960s, some version of Mexican democracy was real.

Scarcely a decade later, however, Mexico's ruling regime received a different reading from both resident and foreign scholars, which was in keeping with the general emphasis on studies of bureaucratic authoritarianism. Starting in the early 1970s, study after study underscored similarities between Mexico and its southern cone counterparts in Argentina and Brazil (Kaufman 1973, 1975; Reyna 1974; Purcell and Purcell 1976; Reyna and Weinert 1977). Mexico's subsequent label as authoritarian was not without qualification, of course, since some scholars claimed that authoritarian traits like presidentialism and the absence of a competitive party were effectively offset by the popular base of the party, the plebiscitary nature of Mexican elections, and the important social policy concessions offered to popular sectors incorporated into the party. Yet, despite added qualifiers to the authoritarian label, such as populist, paternalist, or inclusionary, the overall assessment of Mexico as authoritarian remained.

But then in the late 1980s, the definitional clock seemed to strike a return to the 1960s. The restoration of elected civilian rule in many countries of Latin America rekindled interest in democratization. New society-centered paradigms suggested that Mexico seemed poised on a democratic breakthrough: The urban population had mobilized under the sting of economic scarcity;

3 Of course, even then Mexico posed a special analytical problem to modernization theorists who controlled the definitional terrain: It had a party system, although a noncompetitive one, and a formal equality of citizenship despite deep de facto inequalities wrought by unequal development and bureaucratic corruption. Moreover, its political structures were acquired not through processes favored by modernization theory (urbanization, education, and so forth) but through a revolution institutionalized long before the country became industrialized. These analytic difficulties, however, were generally overlooked by those eager to claim Mexico as relatively democratic because of its political stability and civilian government. 
entirely new political actors emerged in the form of parties and social movements; and a modest electoral reform had been carried out.

Despite this promising preamble, the 1988 elections and the presidential period following them saw a systematic undermining of the incipient multiparty system, the manipulation of electoral outcomes to insure the victory of the official party, and a major regional armed rebellion. The theoretical waters during this period were muddied when Mexico hosted new attempts to reform the official party, which in turn acknowledged some local and state-level electoral victories by opposition parties. Citizens also witnessed a conciliatory style of dealing with armed revolt which bore little resemblance to erstwhile authoritarian solutions to such conflicts. ${ }^{4}$ Yet all these manifestations were combined with the reassertion of a new and formidable form of patronclientelism coupled with growing tendencies to shield all vital economic and financial decisions from public scrutiny. ${ }^{5}$ Not surprisingly then, even though the revival of electoral competition and the rise of social movements spurred some contemporary writers to argue that Mexico was finally experiencing signs of a genuine democratic opening (Foweraker 1990; Cornelius, Gentleman, and Smith 1989), their coincidence with the revival of patron-clientelism and a retrenched presidentialism inspired others to express their doubts regarding the imminence of democracy in Mexico (Aguilar Zinser 1989; Centeno 1994; Cook, Middlebrook, and Molinar 1994).

So the ballot is still out. Not only has there been little agreement at any one time on the extent to which Mexico's system of one-party rule is democratic or not, but scholars' opinions on this issue have shifted over time as conditions and ideas in fashion have changed. Why? What forces or conditions have sustained these vacillating interpretations of Mexican politics; and is there any direct relationship between Mexico's democratic potential and changing conditions on the ground, so to speak? We hope our revised theoretical framework can also shed light on this conceptual problématique and the prospects for democracy in Mexico.

We analyze Mexico during three periods: the much-contested presidential election of 1940 and the subsequent decade; the years heralding and following the 1968 student uprising, which most scholars consider a watershed point in Mexican democracy; and the events surrounding the electoral upsurge of 1988. We seek to establish, first, the changes in the exercise of citizenship (participation and contestation) taking place during these periods; second, the varying measures adopted by the respective administrations to meet citizen challenges (accommodation); and, third, the effects of these measures on the

4 The normal authoritarian reaction was total military annihilation, as exemplified in the 1970s repression of the Guerrero guerilla led by Lucio Cabañas.

5 We are referring here to the negotiations over NAFTA during the Salinas administration and those over the financial rescue by the United States and IMF, followed by the Zedillo government's shock therapy from December 1994 on. 
nature and prospects for subsequent political participation and contestation, and thus for democracy.

In addition to offering a new way of conceptualizing the potential for democracy in what Dahl would call a nonpolyarchic political system by offering an historically specific account of changing patterns of participation, contestation, and accommodation, we hope to challenge the still widely held view that Mexican politics are an endless repetition of "more of the same" interrupted from time to time by crises whose resolution remains epiphenomenal to the conditions sustaining the regime. The "what changed" question is a necessary prelude to theorizing "whither change," such that prospects for democracy are impossible to predict without situating notions of participation and contestation in the real collective experience of actors over time. This requires jettisoning yesteryear's practices of applying these concepts as mere atemporal yardsticks.

One caveat before beginning. Most of the facts recounted in this article are known to the specialist. However, we present them in an analytic framework that gives new meaning to the information already available in primary and secondary sources. As such, even though we rely on the same evidence as other scholars, our subsequent conclusions about the nature, extent, and prospects for Mexican democracy are rather different. In our three roughly comparable narratives we underscore how events in one period in turn set probabilities for subsequent developments. Far from being discovered by our research, then, the historical facts cited for each period both prompt a new reading of Mexico's recent political history and allow a new theorizing of democratic construction.

PARTICIPATION, CONTESTATION, AND ACCOMMODATION

IN HISTORICAL PERSPECTIVE

\section{Heading to Crisis in 1940}

Mexico's 1910 Revolution produced several decades of instability and infighting within the revolutionary leadership which did not subside until 1929, after President Calles created the Partido Nacional Revolucionario (PNR) in order to avert a succession crisis following president Obregón's assassination. However, because the PNR, which excluded the popular classes, was little more than a congregation of quarrelsome caudillos whose consensus was necessary for the regime to survive, it was not until the administration of Lázaro Cárdenas (1934-40), when the PNR was transformed into the Partido de la Revolución Mexicana (PRM), that Mexico's political structures first expanded sufficiently to generate popular legitimacy. The 1936 establishment of corporate sectors for labor and peasant participation and Cárdenas's introduction of new social policies addressing citizen demands convinced many that postrevolutionary Mexico could be designated as relatively democratic, despite the absence of competitive party politics. 
During the last years of Cárdenas's administration, however, the postrevolutionary regime suffered a major political crisis, evidenced by several attempted military coups and the surge of opposition to the official party manifested in the 1940 presidential election in which opposition leader General Juan Andreu Almazán purportedly defeated the ruling party's candidate, Manuel Ávila Camacho (who was proclaimed victorious anyway). In the aftermath of this challenge and in the ways that the PRM responded to greater contestation, growing demands for participation, a potentially rebellious military, and the increased likelihood of an opposition party in power, Mexico's path was set.

Most analysts have focused on the business backlash against labor as the major focus of discontent in Mexico during the late 1930s. This elite-centered explanation allowed many of those concerned with popular participation to ignore the ruling party's falsification of electoral results in 1940. The magnitude of Cárdenas's social and political reforms also made it easier to overlook violations of democratic procedures at the end of his term, as did the fact that, when Cárdenas founded the PRM in 1938, its four-sector structure was a vast improvement on the PNR's substantially more circumscribed political franchise. Prevailing interpretations of the party's democratic character in the years surrounding the 1940 crisis are, none the less, still debatable. Much of the literature leaves out an important source of regime vulnerability, namely, the still overly narrow social composition of the party and the demands which this produced for participation, which ultimately contributed to political and military backlash.

Popular mythology about the Cárdenas years notwithstanding, by the end of the 1930s, much of the population - not only capitalists who feared further pressures on profits but also the middle classes and the urban poor left out of Cárdenas's social reforms-was discontented. Joining them in expressing their dissatisfaction were rural property holders, many of them strong supporters of the Catholic Church, dissident sectors of the labor movement who clamored for greater independence from the state, and military elites who clashed with radical sectors of labor and peasant forces newly empowered by Cárdenas's agrarian reforms. Discontent among the military elites was as much about demilitarization, which Cárdenas sought in order to undermine the power of conservative military elites within the party and state, as about ideology per se. ${ }^{6}$

The problem was that widespread popular discontent could not be expressed through the mechanisms for political participation available at the time. Although by 1936 the labor and peasant sectors were incorporated directly into official party structures, most of the nation's middle classes-and significant portions of the urban poor-had only a tenuous connection to the

6 For a discussion of demilitarization started under Cárdenas and successfully completed under Ávila Camacho, see Lieuwen (1968), Lozoya (1976), and Davis (1995b). 
ruling party. An additional sector created in 1938, initially called the "bureaucratic sector," presumably held the potential to represent the urban poor and middle classes. Yet its function in this regard was only rhetorical, since it was intended mainly as a vehicle for the political involvement of civil servants. ${ }^{7}$

The military also were effectively disenfranchised, despite a fourth sector in the party also created in 1938 expressly to represent them. Cárdenas had imposed new restrictions on the military's involvement in politics, which meant that the new military sector he created had little independent voice in Congress. Although some military elites were still quite powerful, the military sector played only a minimal role in national politics and policy making between 1938 and 1940, Cárdenas having expressly argued that it was not intended to operate as a corporate sector. ${ }^{8}$

In short, even though some segments of the middle class, the urban poor, and the military may have felt represented by the four-tiered PRM in Congress, the inadequacies of the party's sectoral structure, combined with its labor and peasant orientation and its ironclad control of parliamentary debates and legislative procedures, left most of them with very little room for influence. Labor organizations wishing to stay independent of the CTM also had little voice in party or congressional debates. The formal rules of the official party, in contrast, only provided for democratic resolution of political differences among and within the sectors representing loyal industrial laborers, peasants, and state workers, giving each the opportunity to designate a presidential candidate.

With so many Mexicans politically disenfranchised, expressions of discontent soon became an issue of greater concern to party leaders than internal democracy. By late 1938 and throughout 1939, social movements filled the streets of Mexico City, representing the urban poor and middle class groups excluded from the party's sectoral structure. ${ }^{9}$ In one such event in late 1939 ,

7 While there was talk of a popular sector as early as 1937 , its constituency and formal status remained vague. Starting in 1938 with the establishment of the PRM, Cárdenas created a fourth sector of the party (which stood alongside sectors for peasants, labor, and the military), although it was intended for state workers and thus was called a bureaucratic sector. Various other groups were subsequently claimed to be constituents, but they were generally organized on an ad hoc basis to give life to Cárdenas's rhetoric of unity; and they did not participate directly in party activities to the same extent as did bureaucrats. Moreover, this sector's formal composition, juridical status, and power in political deliberations (not to mention the nature of citizenship and electoral rights granted its constituency) shifted at various times between 1937 and 1940. Certain other groups such as teachers and the military rank and file were moved back and forth between different sectors, depending on the political climate of the time. It was not until 1943 that the Confederación Nacional de Organizaciones Populares (CNOP), thereafter known as the popular sector, was officially christened the third institutional sector of the party and that the participatory political rights of its constituents were formalized. See Davis (1995) for the CNOP's history and origins.

8 The military sector was not granted the same privileges as the other sectors. According to Pablo González Casanova (1986:119), it represented military men as individual "citizens," as opposed to that of a corporate body.

9 In a 1936 pamphlet, the independent Confederación de la Clase Media responded to Cár- 
2,000 residents affiliated with the Consejo de Colonos, or the Council of Neighborhood Residents, marched for rent control and housing improvement in poor areas of the city. ${ }^{10}$ Further complicating matters, the conflicts among the sectors for the nomination of a presidential successor in 1939 began to challenge the stability of the post-revolutionary regime in the volatile conditions following oil expropriation. ${ }^{11}$

Given the threat of prolonged intraparty conflict over the presidential nomination, supporters of Ávila Camacho bypassed the PRM's rules and started a selection process that favored their candidate despite the protests of the others. The CTM was eventually persuaded to join in these efforts, ${ }^{12}$ and the CNC followed suit. By the time each of the PRM's sectors carried out their individual conventions, the choice of a candidate was a foregone conclusion. The opposition seized upon this violation of the party's purported internal democracy. Many threw their support to General Almazán, as did a considerable portion of the rural and urban middle classes, dissatisfied members of the military, and those in the independent labor sector. For many, Almazán represented the voice of reason and the return to order after the social turmoil of cardenismo. He offered tranquility for capital and the end of religious strife, both of which appealed to the conservative opposition. He also represented moderate reformism for labor and an end to intraparty domination of electoral procedures, issues of concern even to many PRM loyalists. Most important, perhaps, he seemed receptive to the interests of citizens excluded from the party's formal sectoral structure. ${ }^{13}$

Election day-July 7, 1940-was marked by every possible violation of the norms of fair elections. There were street fights and shootings, voting booths taken by force, and ballots burned or stuffed. Only the Federal District

denas' exclusive embrace of peasant and labor organizations within the party, by demanding the "civil and political rights" of those employed in commercial and professional activities, including the military services (Archivo General de la Nación, 1936).

10 See Davis (1994b:96-97) for more on the proliferation of anti-Cárdenas social movements among urban popular and middle classes in the late 1930s.

11 In 1939 labor, represented by the powerful and relatively militant CTM, sought to nominate a candidate who would continue the policies of radical reform that had characterized the 1934-40 period. Among its potential allies was the peasant sector organized under the CNC, who nevertheless favored General Francisco Múgica, a close ally of President Cárdenas and recognized hero of the Revolution. The military, on the other hand, was divided between a conservative and a more moderate choice. Its potential allies included the urban middle classes, rural property holders, and business leaders who were not yet incorporated into the party's sectoral structures. As a result, a split developed within the party among Múgica, representing the extreme left (and Cárdenas' favorite); Sánchez Tapia, a party man with an ill-defined ideological profile; and General Ávila Camacho, a man considered by most factions to be both moderate and manipulable.

12 Despite its original opposition, Ávila Camacho's candidacy seemed to suit the CTM leadership's intentions of forming a left-center coalition under CTM hegemony. In addition, labor was given the opportunity to help draft the party's six-year plan, a concession that was expected to guarantee CTM influence in the new government's policies.

13 Among other things, during the campaign Almazán advocated private property, opposed agrarian reform, and supported public housing for all, not just for industrial workers, as Cárdenas had proposed. 
remained relatively "clean," with the result that the official party in the capital was defeated. Against clear evidence of considerable opposition strength, the unappealable decision of the Electoral College on August 15 was 2,476,641 votes for Ávila Camacho, against the improbable totals of 125,101 for Almazán and 9,840 for Sánchez Tapia.

\section{Widening Participatory Structures and Restricting Mechanisms for Contestation}

Under these very inauspicious circumstances, Mexico's new president embarked upon the arduous task of reconciling warring factions. Quick to recognize that much of Almazán's support came from PRM members burned by the party's candidate selection process and from those groups (popular, middle classes, and military elites) who felt excluded from party deliberations, President Ávila Camacho (1940-46) took steps to bring them into the party and prevent conflict among them. By reforming the sectoral structures of participation and responding to contestation, many of these conflicts were overcome and citizens were offered palatable enough alternatives to keep them from joining opposition parties. Both developments brought political stability and a new lease on one-party rule.

One of President Ávila Camacho's first acts was to dissolve the PRM's military sector, in order to neutralize the almazanistas in that sector and to eliminate intraparty tensions between the military and CTM. ${ }^{14}$ Second, he named a moderate, Fidel Velázquez, to succeed the flamboyant and more contentious Vicente Lombardo Toledano as the head of CTM, thereby signalling a shift to the right in that sector's ideological profile. Third, he eliminated the freedom of each sector to select presidential candidates. These three restrictive measures were counterbalanced by a fourth major reform that actually widened the party's reach: the founding in 1943 of the Confederación Nacional de Organizaciones Populares (CNOP), an altogether new and third sectoral structure of the party which took the place of the bureaucratic sector. In addition to state workers, the CNOP formally incorporated into the party the middle classes (urban and rural), small businesses and shopkeepers, the urban poor, and military personnel. ${ }^{15}$ In this way, the CNOP stood alongside the CTM and the CNC, or peasant sector, as the third sector of the PRM.

During his first years in the presidency, Ávila Camacho also made deliberate policy efforts to accommodate the party's original constituents, especially labor, attempting to compensate for the lack of internal democratic mecha-

14 Many of these conflicts originated in legislation that Cárdenas introduced in order to extend labor protections to state workers by law, a move that much of the military elite felt (and probably rightly so) was intended to create solidarity between the military rank and file and the CTM, thereby further undermining the institutional power of the military sector. For details, see Davis (1995).

15 While military personnel were not supposed to participate in politics after the demilitarization measures introduced by Cárdenas, in practice many did as leading members of the CNOP. For more on the military and the CNOP, see Davis (1995). 
nisms and the establishment of a new, potentially competitive and more ideologically conservative political sector, the CNOP. While his six-year plan gave guarantees to private enterprise and reaffirmed the right of private property (clear demands of some members of the CNOP), it also provided welfare measures for the labor sector and public employees. Among these were minimum wages, profit sharing, social security, and public housing, all of which were constitutionally guaranteed.

President Ávila Camacho's efforts to incorporate a wide variety of class forces into the party's institutional structures, as well as to cast social and development policy broadly enough to match these new institutional contours, were presented in a program of National Unity, which found fertile support among the CNOP's constituents. He also instituted a Pacto Obrero, or Workers' Pact, signed by representatives of capital and labor, which established the principle of co-determination between owners and workers in the manufacturing sector, in exchange for labor's agreement to abstain from striking. ${ }^{16}$ The Pacto Obrero, however, was soon opposed by leading elements of the industrial bourgeoisie (except, of course, for the no-strike clause). After individual enterprises refused to create internal tripartite commissions capable of overseeing profits and wages, radical and independent-minded unions launched a series of strike actions widely supported by the rank and file. ${ }^{17}$ Several unions (electricians, oil workers, railroad workers) proceeded to walk out of CTM (and therefore also the official party).

In response to the increased contestation from labor, Avila Camacho adopted a double strategy of containing labor through a new labor code while vigorously pushing a languishing social security bill. The first move, accepted by the CTM leadership but opposed by many unions, ${ }^{18}$ made the right to strike contingent upon a complex process of advance notice and state arbitration. The second offered organized labor a comprehensive system of social security. Together, the reforms showed a significant accommodation to rank-and-file demands, although they were combined with more restricted opportunities for contestation.

When the party was shortly thereafter renamed Partido Revolucionario Institucional (PRI) in 1946, it seemed to be but a distant cousin of the PRM that Cárdenas originally founded. The renamed party was much more inclusive in breadth and class diversity, but the democratic procedures for pre-

16 The Pacto Obrero was originally intended to establish the institutional foundation of a new kind of industrial order. Through the legal principle of tripartidismo (tripartite decision-making), it defined the legality of co-decision between labor capital and the state. A Consejo Obrero (Worker's Council) would sit with representatives of capital and the state on a National Tripartite Commission endowed with wide powers. Simultaneously, factory-level committees would be entrusted to define the appropriate levels of profits and wages.

17 Barely three months after the pact had been signed, the number of strikes went from 19 in 1942 to 562 in 1943 and 721 in 1944 (Rivero 1990:39).

18 See Loyo (1990:90). 
candidate selection were gone and even if the labor and peasant sectors now shared the formal political terrain with the moderately conservative CNOP. Moreover, even though no written rules explicitly prohibited individuals in the three sectors from voting against the candidates selected by the PRI, de facto practices established during this period insured that this was virtually impossible. These new institutions, in short, both extended and restricted democratic practices with respect to the previous period.

\section{Edging Towards a New Crisis: The Explosion of 1968}

The 1943 restructuring and 1946 revamping of the official party held many promises of participation and demand articulation. Many were actually fulfilled, leading to a decade of political calm in Mexico that was reinforced by an expanding economy and standard of living gains due partly to the pacts forged between capital, labor, and the state. The inclusion of middle classes helped stem civil opposition to one-party rule and offered the possibility of greater internal contestation. Yet all was not perfect. By the late 1950s a new crisis arose for the PRI. Much of it revolved around conflicts among, and between, its working and middle-class political bases. Greater state control over union leadership during the 1940s and early 1950s, for example, kept the party's middle-class constituents loyal but alienated many in the union movement, who then rebelled, only to be repressed in the 1950s and 1960s. ${ }^{19}$ At the same time, a growing slice of the country's conservative middle classes became disenchanted with the party, in part because of leftist influence in the nation's educational system that resulted from the political power of radical teachers in the CNOP (Loaeza 1988). In an effort to stem further middle class opposition the party overhauled its educational programs and repressed radical labor and teacher movements. The result was growing contestation both within the party and outside, especially on the part of middle classes and radical labor movements - both in the CTM and CNOP - as they struggled over the ideological character of the party. ${ }^{20}$

During this period, problems in the national economy brought a new economic model in 1958 (called stabilizing development), which also spurred a round of strikes from even loyal union constituents. The government responded by placing more substantive democratic reforms on the agenda. With increased contestation as a backdrop, in the early 1960s the PRI introduced a cosmetic electoral reform which allowed for token representation in National Congress of a more diverse array of opposition parties. This move avoided

19 We are referring here to the forceful suppression of union democracy within independent unions through fraudulent internal elections which took place between 1946 and 1948 and to the repression of the railroad workers movement under the leadership of Demetrio Vallejo in 195960. For details of these episodes, see Brachet-Márquez (1994a).

20 Inside the party, doctors organized within the CNOP went on strike and posed a major challenge to the sectoral leadership; while outside, members of the middle class were among the most likely supporters of regional opposition movements, such as the Navista movement, which had emerged to challenge the (spatial) centralization of politics associated with one-party rule. 
any real congressional challenge to the official party, so substantive political deliberations changed very little. Thus, although contestation continued, PRI initiatives prevailed, as did relatively widespread albeit frequently silent support for the ruling party.

This state of affairs did not last long, however, as the PRI subsequently faced problems stemming from the disjuncture between formal and substantive political participation. Even though the formal mechanisms of participation were extended during this period (as with the 1963 electoral reform), other new institutions within the party further restricted the social bases of participation and narrowed the range of opportunities for contestation. For example, the 1965 creation of the Congreso del Trabago (CT, or the Work Congress), a new umbrella organization intended to form a bridge between the CTM, more independent elements in the organized labor movement (such as electrical, oil, and railroad workers) who had walked out of the CTM in previous decades, and such troublemaking state employees from the CNOP as teachers, increased the power of a narrow substratum of players while effectively excluding other loyal party members from greater participation.

The CT's foundation may have helped overcome sectorally based splits in the labor movement, bringing a precarious unity of labor around the PRI and helping labor make forceful wage and workplace demands. With labor peace, the administration was freer to push the growth-generating model of stabilizing development. But these achievements, despite appeasing labor's longstanding demands, challenged the viability of the three-legged corporatist structure. With the largest and most powerful group from the CNOP (teachers) now integrated into a new institutional body along with leaders of various other industrial labor organizations, the CNOP's and CNC's independent sectoral voices within the party were substantially weakened, as were the possibilities for them to raise a wider range of controversial issues. The subsequent suppression of sectoral voices calling for a democratic reform of the PRI is a case in point. 21

By the late 1960s, those dissatisfied with the party and its policies once again posed a threat to the political status quo, especially as the model of import-substitution and industrialization that Mexico had pursued had begun to show signs of strain. While big capital and much of organized labor were relatively well-equipped to weather the economic strain, many other groups were not. ${ }^{22}$ Indeed, when a round of unprecedented inflation started to hit

21 An early 1960s proposed reform of the party's electoral procedures to introduce a system of primaries for the selection of candidates actually came from within the party itself under the leadership of Carlos Madrazo, the party chief.

22 Over the late 1950s, large industrial firms cultivated strong links with foreign manufacturers and banking institutions that gave them financial and market leeway when the Díaz Ordaz administration (1964-70) sought to cut back on protectionism. The stronger bargaining position of big business with the government is illustrated in Davis (1994b), Fagen and Tuohy (1974), Story (1986) and Teichman (1988). 
Mexico in early 1965 and 1966, the groups experiencing the most difficulties small businesses, shopkeepers, laborers from non-union smaller factories and semi-artesanal shops, ${ }^{23}$ seasonal workers, and informal sector workers-were largely excluded from the newly formed CT, which now replaced the party's institutional sectors as the preferred setting for negotiations with the state.

With the crisis of import substitution coinciding with a fundamental restructuring of the mechanisms of participation and contestation within the party, political dissatisfaction hit a new peak. Among those most mobilized were middle class professionals, students, and organized workers in industries represented by a sprinkling of independent unions. Each group had a different reason for being unhappy with the regime but merged with others to oppose government policy. The middle classes were especially disturbed by the repudiation of efforts to democratize the PRI internally. Students objected to new educational policies that restricted entrance and limited opportunities for democratic control of universities. Independent labor unions found that the new CT coalition increasingly squelched their ability to organize and to voice alternative priorities. When in the spring of 1966 an initial series of clashes between National University (UNAM) students and academic authorities saw the former's failure to be recognized as political protagonists, ${ }^{24}$ middle classes and independent laborers lent sympathy.

The 1968 Tlatelolco tragedy emerged from these student protests. Mexico endured a mounting spiral of student protest and police repression which mobilized students and non-student protesters (workers, peasants, and popular middle classes) against police violence and state authority. Ten thousand demonstrated in July 1968 against the government's unlawful indefinite closing of all universities and high schools. During another student mass rally in Tlatelolco on October 2, police cordoned off a middle-class housing project in the heart of Mexico City. Thousands were killed or taken prisoner by riot troops. ${ }^{25}$

${ }^{23}$ Many of these small workshops were family businesses with less than the mandatory minimum number of employees for obligatory unionization. Yet this very numerous category played a crucial role in Mexican industrialization, providing big business with cheap components for their mostly high-priced manufactured products.

24 Although the policy initiatives that led to this early clash were shelved, several unfortunate precedents were established for handling subsequent citizen mobilizations. First, the university had shown its inability to control the student body without relying on the deployment of police force, thereby endangering the principle of university autonomy. Second, the support which student protesters had attracted from parents and faculty had shown the capacity of mobilized populations to strike a sympathetic chord among politically strategic social groups, especially that of the middle class. Also, the very thin line dividing high school from university education in Mexico had briefly broken, letting in a much larger pool of potential contestants than the relatively small number of those admitted into college.

25 In 1993, the radical weekly, Proceso, took advantage of the U.S. Right to Information Act to discover that Pentagon documents issued by the government indicated that the riot troops had orders to repress the demonstration. This is contrary to the official explanation, which maintained that the shooting was started accidentally. 


\section{Democratic Opening}

The Tlatelolco massacre, considered by most analysts a landmark in Mexico's recent history, demonstrated to millions of Mexicans that contestation in Mexico was punishable by death or indefinite imprisonment. With a serious political crisis on the horizon and in the limelight of the 1968 Olympic Games which Mexico was hosting, politicians and government leaders scrambled to introduce a series of reforms, most of which would be implemented by Gustavo Diaz Ordaz's successor, President Luis Echeverría (1970-76). The latter encouraged the greater political participation of previously excluded groups and attempted to re-establish greater accountability towards them.

Most significant for our purposes, Echeverría publicly committed his government to being open to democracy and brought a younger generation of opposition intellectuals directly into his cabinet. He also established a system of local neighborhood associations (Juntas de Vecinos) in Mexico City, where much of the mobilized opposition to the government resided, thereby encouraging the organization of communities linked directly to state agencies. As a result, citizens who had substantively (if not formally) been excluded from the party's sectoral structures now had a channel for participation. Far from leaving out organized labor, Echeverría also called for union democracy and offered a very generous housing policy. Initially designed to reconcile mainstream and independent labor groups, this program was enlarged to include civil servants and the urban poor, who also received important, though less substantial, housing plans. ${ }^{26}$

The political and social reforms introduced by Echeverría not only helped reinforce participation but also encouraged greater contestation in general, creating more legitimacy and accountability for one-party rule. Independent unions, much to the discomfort of the CTM leadership, now could actively challenge the old-guard labor sector, and urban populations had both incentives and new political structures in which to make demands on the state without mediating their claims through the party. In addition, intellectuals and professionals were offered a freer press. Together these reforms insured the PRI relatively strong support among these social groups. Thus, even as the fiscal crisis that hit Mexico in the final years of Echeverría's term ballooned into an international debt crisis under his successor, Jose López Portillo, Mexico still appeared remarkably stable as it entered its sixth decade of oneparty rule.

Nonetheless, the debt-produced economic crisis during the last year of the López Portillo administration (1976-82) brought to the surface problems latent in earlier accommodations and in the expanding scope for participation and contestation. The future of one-party rule was in question for the first time

\footnotetext{
26 For further discussion of housing and urban policy actions during the Echeverría administration, see Aldrete Haas (1991) and Davis (1994b), respectively.
} 
since 1940. The collapse in 1981 of petroleum-led developmentalism virtually eliminated the safety valve of state accommodation that had previously kept contestation low and participation sufficiently high to sustain the PRI's support. Mexico was plunged into the deepest and longest economic crisis of its history, manifested by massive capital flight, towering foreign debt, record unemployment, triple-digit inflation, and widespread de-industrialization.

This sudden crisis profoundly transformed the nature of political participation in Mexico. Emboldened by new institutions and policies, citizens revived the dormant practices of societal contestation. Given the rapidly deteriorating economic situation by the mid and late-1980s, under the Miguel de la Madrid administration (1982-88), many citizens shifted allegiances from the PRI to opposition parties and urban and regional social movements. ${ }^{27}$ In October 1983, the Coordinadora Nacional de los Movimientos Urbanos Populares (CONAMUP), or National Coordinator of Popular Urban Movements, ${ }^{28}$ an independent, urban-based, grassroots organization created during the late 1970s, mounted a gigantic civic strike (paro cívico) in Mexico City to protest inflation and the high cost of living. ${ }^{29}$

Perhaps the biggest blow to the party came later, when it became clear that the CTM's capacity to call strikes was almost spent, as was its ability to guarantee wage increases despite high inflation. The government began to repudiate strike actions and shunned negotiations with labor leadership when they occurred. The decline of formal sector employment also depleted the ranks of the organized labor movement and pushed many to become concerned about issues of daily survival (housing, health, transport, water, electricity) rather than salaries or workplace demands. As a result, established participatory structures like the CTM and the CT now held increasingly smaller portions of the politically activated population. Even employed industrial workers (especially in Mexico City, where a majority resided) increasingly supported neighborhood-based urban social movements more than the party's labor sector.

As millions turned to grassroots organizations rather than the PRI to voice

27 Some of the shift in political support owed to the fact that, with the economic crisis, there were few fiscal resources available to the PRI to continue accommodating the social policy and cost-of-living demands of the people. In this context, the party prioritized organized labor over other groups. This fueled the organization and opposition of neighborhood and other social movements that represented consumers. For more on this, see Davis (1990).

28 Apart from the CONAMUP, other coordinadoras included the CNTE; Coordinadora Nacional de los Trabajadores de la Educación (National Coordinator of Educational Workers), representing the "democratic tendency" among teachers and the CNPA, and the Coordinadora Nacional del Plan de Ayala (or National Coordinator of the Ayala Plan), the independent peasant movement. For more information on coordinadoras, see Hernández (1987) and Carr and Anzaldua Montoya (1986).

29 Approximately two million protesters participated, emboldening the CT to renew wage demands that the administration had previously rejected. The following year, the CTM threatened to call a general strike unless wages were raised. This threat was backed with scores of strike announcements. In June, a second paro cívico was staged, mobilizing about 500,000 people. 
their urgent economic demands, the PRI itself was undergoing an internal crisis: A group referred to as the "democratic tendency" demanded the democratization of the party. Rather than face the possibility of unmanageable internal contestation, party leaders chose to expel the dissidents, many of whom were party activists from the Generation of 68 who had become involved during the Echeverría administration. A considerable number of them, however, were longstanding party members, including Cuauhtémoc Cárdenas and Porfirio Muñoz Ledo, who both jumped ship in a much-publicized break.

The departure of previously loyal party leaders like Cárdenas led to mass exodus on the part of the party's rank and file, especially critical sectors among labor and teachers. ${ }^{30}$ The middle classes, historically concerned about democracy, actively shunned the formal structures of participation-whether the CNOP or the Neighborhood Associations introduced by Echeverría-and instead publicly voiced their demands. ${ }^{31}$ The urban poor, who served as the backbone of the grassroots movements struggling against the administration's austerity measures, also supported the dissidents. Notably, many of these groups, as well as Cárdenas and Muñoz Ledo themselves, had once served as the mainstay of the CNOP, which was now barely functioning.

This shift in loyalties was made visible in the 1988 presidential election, in which Cárdenas ran as an opposition candidate heading The Frente Democrático Nacional (FDN) and capturing the enthusiasm of the crowds. Born of a merger between the ousted democratic wing of the PRI and several leftist parties, the Frente gained enough electoral support from the middle classes, independent labor, and the urban poor to nearly capture the presidency. That Cárdenas was the son of the nation's champion of agrarian reform, Lázaro Cárdenas, also helped him gain critical support in a few key rural areas, especially his home state of Michoacán. But when it was announced that Carlos Salinas de Gortari, the PRI's candidate, won by 10 percentage points, hopes of substantial democratic reform either within or outside the party vanished. ${ }^{32}$

\section{Shedding Old Structures and Seeking New}

As the de la Madrid administration made its inglorious exit, it was clear that the official party had lost most of its traditional virtues while acquiring few new ones. The policies of privatization and deregulation started in the 1980s

\footnotetext{
30 While teacher opposition to governmental policies was clearly represented by CNTE, the dissident teachers' coordinadora, dissent in the ranks of labor was more unobtrusive. The only union that openly stated its opposition and publicly boasted of financing the campaign of the Cardenist National Front (FDN) that ran against the PRI in 1988 was the oil workers' union, which later paid dearly for its insubordination when its leader was jailed just after President Salinas de Gortari took office.

31 For a discussion of divisions within the PRI over democratic reforms, its implications for the CNOP's diminished institutional capacity and the way this articulated with social movement pressures, see Davis (1989).

32 Most scholars and observers contend that Cuauhtémoc Cárdenas in fact defeated Carlos Salinas de Gortari.
} 
blocked its capacity to distribute the accustomed prebends to sector leaders who, in turn, could no longer command obedience from the rank and file. Marginalized from decision making and internally divided between the "dinosaurs" 33 and sundry renovating forces, the party had seemingly lost its capacity to ensure electoral success.

Following its doubtful electoral victory, the Salinas administration (198894) embarked upon a bold program of "social liberalism" intended to restructure the economy while rebuilding the badly damaged legitimacy of the party-state. This was to be achieved through party reform, coupled with a new form of presidentialism made palatable by a strategically targeted welfare package - the National Solidarity Program (Pronasol). ${ }^{34}$ Under the new leadership of Donaldo Colosio, the PRI was to become a party of individuals (as opposed to unions) responsive to the preferences of the rank and file. New measures included the greater incorporation of local leaders (replacing the accustomed centrally controlled system of appointments); the institution of primaries; and the creation of a national council in charge of selecting the presidential candidate, which replaced the process of anointment by the outgoing president (Dresser 1994).

In an effort to reopen the party to independent groups (and therefore also to greater internal contestation), the new leadership announced that CNOP would be replaced by UNE, Ciudadanos en Movimiento (Citizens in Movement), which would include not only old constituents of the CNOP but also the newly activated social movements and any unions that wished to join (thereby depleting the ranks of CTM). The transformation of the old CNOP into the UNE was short-lived: Few independent groups were inclined to be swallowed up, once again, by yet another sectoral structure. Barely two years later the UNE was disbanded, only to be replaced in 1993 by the Frente Nacional de Organizaciones y Ciudadanos (FNOC), or National Front of Organizations and Citizens. ${ }^{35}$

After efforts to reform the party's structures produced confusion and relatively little new participation or grassroots support, ${ }^{36}$ President Salinas began to shift the capacity to make policy out of the party's hands and into the executive branch. Obviously, since Salinas still bore the mantle of the PRI this did not mean a complete severing of ties with the party; but the party leadership no longer had the same authority to mediate, let alone accommodate,

33 This was the name given to the old sectorial cadres of the PRI, the most famous and oldest one of them being Fidel Velázquez, now past his ninety-sixth birthday.

34 It has been said that, even before the result of the election was known, the Salinas camp was rebuilding its popular alliances and that Salinas had appointed a "political cabinet" to head this effort (Haber 1994a).

35 For discussion of the CNOP's sectoral transformation to the UNE and then the FNOC, see Davis (1995).

36 In fact, as this article goes to press, a proposed party reform calls for the CNOP to be reinstated. 
demands from its sectoral constituents. This was perhaps best evidenced by a number of key social programs directed at the poor under the name of Programa Nacional de Solidaridad or Pronasol, run directly out of President Salinas's office, thereby bypassing old party leaders and corporatist participatory structures. ${ }^{37}$

To be sure, Pronasol did embody some governmental responsiveness to citizen demands about poverty, scarcity, and unacceptable social conditions. It also offered unique features of citizen participation through co-management and co-financing that suited the pragmatic action-oriented apolitical mood of the urban movements (Haber 1994a). Yet apart from the health services offered by IMSS-Pronasol (a direct heir to the previous two administrations' IMSS-COPLAMAR), the program was highly restricted in its scope. Rather than acting as a general poverty program that improved distribution, Pronasol targeted only those among the poor whom the president regarded as politically vulnerable (Dresser 1991; Brachet-Márquez and Sherraden 1994; Cornelius, Craig, and Fox 1994; Haber 1994b; Molinar Horcasitas and Weldon 1994). Citizen participation was guaranteed only in the administration of individual local projects, moreover, not in any larger or established political domain (that is, the party and its sectors, congress, or the executive branch). Pronasol, in short, launched a new form of presidential, not party, clientelism built on individualized rather than sectoral participation. ${ }^{38}$

Government efforts to restrict or coopt political participation are no stranger to Mexican politics, and to that extent many see Pronasol as just another episode in a long history of managing contestation. Yet something was different about this strategy of accommodation. In most earlier periods, the government responded to the demands of groups as class-based collectivities, organized in and through the formal sectoral structures of party politics. Groups may have been institutionally divided from each other, but demands were collectively channelled through the occupational and class groupings that found a home within the party's three corporatist sectors. By contrast, Pronasol was structured to individualize, not collectivize, citizen demand making and state response.

Salinas's social policies temporarily solved the accommodation impasse that precipitated the political crisis of 1988, and to that extent his administration was relatively successful in balancing participation and contestation through accommodation, although on a markedly reduced scale. Salinas's strategy also benefitted the party at election time, especially given the govern-

37 For an insightful account of Pronasol, see Pécaut and Prévôt-Shapira (1992) and Cornelius, Craig, and Fox (1994).

38 In a recent article, Fox argues that the transition from clientelism to associational autonomy is replete with setbacks and that enclaves of authoritarian clientelism and semi-clientelism can persist long after pluralism and autonomy have become the dominant associational pattern (Fox 1994). This is illustrated here in the ways that Salinas reestablished clientelistic ties capable of monitoring and rewarding voting behavior, even while clientelism decayed in other official structures, due to lack of patronage resources. 
ment's capacity to monitor electoral results. Despite occasional clashes between president and party, such as the Guadalajara gas explosion, both seemed buoyed by the citizens' relatively positive response in the 1991 legislative elections and again in the 1994 presidential contest.

To be sure, some of PRI's electoral gains during the Salinas administration can probably be explained as much by the party's reform efforts, in response to the challenge of presidential clientelism, as by the Pronasol strategy itself. Moreover, the rift between the president and the party dinosaurs gradually subsided, as the combination of the political climate created by the armed rebellion in Chiapas, the failed economic miracle, capital flight, political assassinations and sundry public scandals endangered the PRI's prospects in 1994. As such, the PRI's victory in August 1994 was also due to a combination of the people's fear of uncertainty and campaign irregularities that systematically blocked the PRD's proselytizing efforts while sparing those of the PAN. These results were obtained at the cost of a vast campaign of misinformation regarding the impending economic disaster, whose effects were postponed for a few strategic months at the cost of plunging the country deeper into financial crisis.

Since Salinas's successor, Ernesto Zedillo, assumed power in December 1994, conditions have rapidly deteriorated. A severe financial crisis, publicly recognized as the cost of upholding Salinas's popularity and keeping the party in power, sets strict limits on the administration's capacity to respond to demands. Open contestation continues nonetheless, exemplified in a national plebiscite organized by the Alianza Cívica, the broad support for the Zapatista Army of National Liberation (EZLN) in Chiapas, and the more recent emergence of an additional guerrilla group, the Popular Revolutionary Army (EPR). Yet much of this contestation is operating largely outside of the party's reach, lacking explicit institutional contours. Moreover, the absence of sufficient fiscal resources to accommodate specific economic demands, the new administration ignores many of the demands from party loyalists and concentrates on reordering the economy as a whole, on negotiating a democratic transition with the opposition (parties and the EZLN), and on severing ties between the party and the presidency. Zedillo's promises of political reform involve electoral contestation within the party, but they do not have the same commitment to social justice, seen as just another obsolete relic of a repudiated past.

Some aspects of the Zedillo program may satisfy minimal definitions of formal democracy, yet policy responsiveness is lacking, without which no democracy can survive in the long run. In other words, with the crisis of 1994-95, the cycle from party-threatening contestation to loyal participation obtained through accommodation may have finally come to its natural end. But what appears to be replacing it is a political system largely devoid of substantive choices for a critically impoverished population and a severely damaged economy. 
COVARIATION AND HISTORICAL SEQUENCING: CASTING NEW LIGHT ON MEXICO'S DEMOCRATIC POTENTIAL

\section{Theorizing Covariation and its Democratic Implications}

Several key findings deserve comment. First, it is clear that participation, contestation, and accommodation-our three indicators of democracy-did vary enough within and across each period that no general conclusion with respect to democracy can be drawn. Postulating that democracy existed only in periods when all three dimensions were high would only lead to the uninteresting conclusion that Mexico has never been democratic. While in some senses this may be true, it tells us nothing about important differences over time in the behavior of key state and social actors, and thus whether Mexico's noncompetitive political system could be considered more or less democratic at distinct historical moments.

Tracking commonalities and differences in the constellations of these three factors sheds more light on political and institutional dynamics and the ways they may have stymied or reinforced one-party rule, thereby making democracy more or less likely. During each period, structures and practices of oneparty rule were called into question when significant portions of the citizenry were excluded from official party mechanisms for political participation. Generally, when party exclusion was high (or participation low), either formally or substantively, societal contestation was high and vice-versa. This combination of low participation and high contestation, in turn, generally brought governmental accommodation, usually in the form of more broadly cast structures of participation but also sometimes more inclusionary social policies. Thus, although contestation was usually discouraged (except for a short period under President Echeverría), there was scope for accommodation, once contestation emerged, in contrast to the classic model of authoritarian systems. Needless to say, our periods varied greatly in the kinds of policies offered and in the class and social identities of the groups benefiting from them. Yet in each period, not only did contestation and participation continue, attempts were made to meet the demands of the groups demonstrating the greatest potential threat to the viability and legitimacy of party structures.

These findings depart from prevailing views of the Mexican state as controlling and preemptive (Collier 1982; Hellman 1983; Eckstein 1977; Reyna and Weinert 1977; Reyna 1974) and instead sustain those emphasizing the government's potential for reacting to system-threatening mobilization (Stevens 1974; Purcell and Purcell 1980; Smith 1991; Brachet-Márquez 1994a; Nugent 1994). But we differ from both bodies of literature in our account of the process that leads to accommodation as well as our assessment of its character. Most interpretations of Mexican politics emphasize the tendency of the regime to discourage broad collective mobilization and respond only to disaggregated demands (Cornelius 1975; Kaufman 1975). Accordingly, those 
who recognize some form of accommodation generally assume prior state preemption that has restricted the terrain for contestation.

Our view is different. Accommodation is not associated with a narrowing of demands, but the opposite: State accommodation brings an expansion and widening of participation and demands within party structure. Indeed, the institutional scope for political participation grew larger as the state continually responded to mobilization by extending the institutional contours of the official party. The CNOP's foundation in the 1940s and that of the UNE in the 1980s are cases in point. Of course, both of these reforms reflected an expansion of demand making that was confined to party structures; and thus, they corresponded to a narrowing of political space for demand making in society at large. Nonetheless, more groups were admitted into formal party structures to participate and make demands.

Demand fragmentation within the party, so often identified by Mexican scholars, is also present. Splits between sectoral leadership and rank and file did grow over time, and they are well documented in the literature, especially in discussions of the party's labor sector (see Calagione et al. 1992; Trejo Delarbre 1986; Roxborough 1984). However, we found that much of this fragmentation owed as much to the unanticipated consequences of institutional inclusion and the timing of the expansion of participatory structures as to the political elite's purposeful efforts to divide political constituencies. For example, the foundation of the CNOP in the mid-1940s and the CT in the mid-1960s were intended to be accommodations to contesting labor groups who felt they deserved their own more powerful and streamlined political structures within the party; but the effect was to split-or fragment-the CTM and CNOP.

Distinguishing between these different routes to fragmentation has clear implications for our assessment of prospects for Mexican democracy. In the prevailing literature, the fragmentation of demands is associated with the regime's authoritarian and purposeful limitation of democratic practices. From our vantage point, however, it is the unanticipated consequence of the state's efforts to preserve the system's inclusionary character. The historical dynamics of this process are clear: As the boundaries of political participation within party sectors expand at particular historical moments to admit new groups, the aggregate demands posed by the party's constituents became more diverse. One consequence is a greater centralization of decision making in the hands of party leaders to offset growing centrifugal tendencies. Another is an increasing inequality of power and influence within the party itself, especially between sectors, since those sectors with greater internal coherence (such as the labor sector) can more effectively wrench benefits from the state than heterogeneous constituencies such as the popular sector. A third critical consequence is the attempt to make the demand structure more manageable through the establishment of cross-sectorial alliances (hence the CT) privileging some 
groups (generally labor and state workers) while de facto disenfranchising others (mainly rural populations, the underemployed urban poor, and the unorganized middle class).

Over time, this dynamic of contestation, accommodation, and greater participation leads to increased political dissatisfaction with one-party rule, even though the source rests in the party-state's efforts to widen structures of participation through accommodation, not narrow them. In short, over time greater accommodation and participatory inclusion generate greater fragmentation within the party and greater dissatisfaction with one-party rule as a whole.

\section{Societal and Party Domains}

How do we reconcile the clear evidence of ongoing contestation, state accommodation, and participatory inclusion with assessments of Mexico as nondemocratic? Our findings suggest that the answer rests in how these processes unfold in both the party and society. In all the periods, both party and societal domains of political action were a potential target and source of struggle for more political participation, contestation, and accommodation. In these struggles, the three principal issues at stake in the government's response were how inclusionary (or exclusionary) should formal structures of political participation become in the future, what sources and forms of contestation should be tolerated, and who should benefit from the political and social reforms accommodating the demands of contestants. Since the PRI was generally unwilling to democratize across all three fronts simultaneously, its efforts to open or close mechanisms for participation, contestation and accommodation often entailed moving demands from one domain to the other. For example, party leaders generally introduced internal party accommodations when contestation within civil society threatened social or political order. They would minimize all forms of political participation and contestation not under the control of the party or some other institutional watchdog or create new structures that would move mobilized citizens directly into party domains (for example, juntas de vecinos). Over time, this dynamic gave the appearanceand often, reality - of greater democratization, at least as reflected in greater participation and contestation, although it remained tied to party domains. Through cumulative institutional reform, political leaders widened the scope of participation and contestation within the party but not within society at large. Stated simply, greater participation, contestation, and accommodation within the party tended to be inversely related to the participation, contestation, and accommodation in civil society.

Although the concept of balance has been of primary concern to many scholars of Mexico, few have applied it to the changing interactions of party and societal domains. Most scholars either assume that opportunities for democratization are located primarily in civil society, and thus can be assessed 
by examining the scope for participation in grassroots (such as non-PRI) mobilizations (as in Foweraker and Craig 1990), or that political participation is to be understood primarily within the party through a focus on the opportunities or constraints on sectoral participation and party decision-making (as in González Casanova 1970). Few scholars assess both domains simultaneously and the balance between the two. Accordingly, the conclusions about democracy vary, depending on whether scholars take as their point of departure formal party politics or civil society. Recently, more scholars are focusing on the nexus of state and society in Mexico and on the ways in which relations between the party and civil society are now in transition (Cornelius, Craig, and Fox 1994; Fox 1992; Brachet-Márquez 1994a, 1994b; Cornelius 1996). But most of these works have not traversed both terrains historically and have, therefore, not charted the paradoxical ways in which democratic possibilities can expand in one domain while contracting in the other.

\section{From Sectoral to Longitudinal Balance}

Once we recognize that increased scope for political participation in the party fuels the cycle of contestation and vice-versa, it becomes clear why the history of Mexican politics has been that of accommodation in the form of implementing institutional and social policy reforms. System-challenging participation and contestation have forced a degree of state accountability because they temporarily improve the bargaining position of selected political actors who could then make additional claims. Of course, the limitations of one-party rule made it unlikely that full participation, contestation, or accommodation in both party and society - what we mean by full democracy-could ever be achieved. This increasingly evident constraint on the system's democratic potential notwithstanding, for several decades both the party and Mexico's citizenry seemed relatively content with party institutions and practices that were constantly revamped to accommodate the latest demands. By implementing these changes, Mexico's PRI could therefore claim legitimacy as well as some approximation of democracy, if it were understood to be the government's response to citizen demands.

These findings dovetail with those of Peter Smith (1991:336), who argues that the stability of the Mexican political system was due to its overall legitimacy, which "rested on the acceptance and participation of sectoral leaders, and entailed the belief - or myth-that redress of particular grievances and advancement of general interest would always be possible; the watchword of this system was 'balance." "Like Smith, we found that establishing symmetry between demands and government responses has been essential to the reproduction of the regime; and we agree that political legitimacy rests on the regime having convinced the majority of Mexicans of its commitment to redress particular grievances and advance social justice. But our conclusions differ from his in three ways. First, we show that system legitimacy rests not 
in the sectoral leadership and its manipulative pre-emptive actions, but in the veritable extension of new opportunities for political participation and contestation for citizens in society and the rank and file in the party as a whole. If anything, the actions of sectoral leaders have threatened — not buttressed - the system's legitimacy. Second, we argue that legitimacy rests not just in beliefs or myth, but in concrete policy decisions that help meet demands, circumscribed in scope as they may be. Third, we contend that legitimacy rests not in a "balance" established in given moments, but sequentially over time.

This third point deserves further elaboration. Most scholars of Mexico draw conclusions about the nature of the Mexican political system from specific mobilizations and state responses, either in a particular historical moment (often the most current) or from some distant vantage point that provides a general assessment of the past and present. Although both of these approaches provide some insight, they fail to examine variations in mobilization and state response over time, especially how present actions are grounded in the past. As a result, scholars have missed the significance for democracy of the historical give and take between the state and societal actors. The theoretical implications of this become clearer if we contrast our conclusions about the source of regime legitimacy with those offered by Peter Smith.

As just noted, Smith sees legitimacy as resulting from each administration's capacity to balance the demands of all its constituent groups, generally by "retain(ing) the notion of access for all and supremacy for none" (1991:336). We argue, in contrast, that legitimacy originates in the repeated efforts of the state's elites to respond to various different demands sexenhio after sexenhio, not necessarily their success in balancing constituent demands at one historical moment. After all, our findings show that balance is never really achieved, in part because accommodations intended to establish balance at one moment almost always generate new forms of participation and contestation (and sometimes even new forms of exclusion), which in turn generate new demands not yet accommodated. Imbalance at a given moment does not thwart the ruling party's legitimacy, so long as political leaders demonstrate some commitment to rectifying it in the future, as seen in their willingness to continue to respond to new groups and to patch up problems created by their past actions. It is the commitment to longitudinal balance, if you will, that makes the political system appear relatively dynamic, adaptive, and responsive, and therefore legitimate, even when such balance is never achieved at any one moment.

This historical approach leads to different conclusions about Mexico's democratic potential because it helps reveal the conditions under which populations accept or reject as legitimate the regime's hold on power. To the extent that the state is seen as having accommodated popular demands and is likely to do so in the future, the regime is accepted as legitimate, even if some present demands remain unmet. However, if certain sectors of the population experience long-term exclusion and feel that future accommodation is unlike- 
ly (as with the changes in Article 27 of the Constitution, which relinquish the state's protection of the peasantry and with the Zedillo administration's abandonment of most social programs), they are bound to join contestatory movements outside of the official party and repudiate one-party rule altogether. The recent rural rebellions - whether conciliatory, such as the Zapatistas in Chiapas, or less so, as with the Popular Revolutionary Army rooted in several poor rural states - are cases in point.

The historical view, moreover, can explain why there have been more struggles for democratization in the current period than in the past, even among previously loyal party members. It is not just that recent administrations have abandoned a longstanding commitment to accommodate demands from citizens and party constituents. In addition, many Mexicans no longer support the government because they interpret today's abandonment in the light of a steadily accumulating history of unfulfilled promises. ${ }^{39}$ They have collectively learned, so to speak, that the party-state is, now, and most probably will continue to be, incapable of accommodating their demands.

\section{Whither Democracy in Mexico?}

What can we conclude, then, about the potential for democracy in Mexico and its variation over time? Our argument about the sequencing, historicity, and domain shifts in participation, contestation, and accommodation leads to one answer: The Mexican political system may have come closest to democracy in the middle years of its life, from the late 1930s through the early 1970s, when the opportunities for contestation, participation, and accommodation were greatest in both party and civil society. Before 1938, party membership was narrowly defined, and large sections of civil society lacked access to formal mechanisms for expressing their demands, except through electoral protest. The overall potential for full citizen participation was therefore low. But starting with the initial widening of party structures under Cárdenas and later with Ávila Camacho in 1943, the size, scope, and relationship of both domains was such that the system's greatest democratic potential was achieved. Incentives existed for societal and party contestation and for accommodation (since there was still scope for more inclusion or party participation). Moreover, party inclusion was not so great as to overwhelm independent political demands.

By the late 1970s, however, the situation became almost the inverse. Party structures were widened so extensively that the independence of civil society became highly circumscribed. The political incorporation of dissident forces and social movements limited the prospects for the citizens' free and independent expression of their political will. Ever-greater party incorporation not only sapped organizational strength from independent movements and weak-

39 This point has repeatedly been made by Subcomandante Marcos, the main spokesperson of the Chiapas armed rebellion, in several of the documents which have been published. The indigenous people of Chiapas have mobilized because of a long history of agravio, a term which by itself conveys accumulated resentment (EZLN 1994). 
ened their leadership, it also increased the heterogeneity and bureaucratization of the party. This meant that interest groups were pitted against each other within the party in a manner that diminished each one's voice and led to a further centralization of the party's leadership and of the state. These trends further circumscribed both formal and substantive participation in the party. As a result, by the late 1970s there was limited incentive for contestation in the party as well, and accommodation and participation declined accordingly. Much of this occurred, paradoxically, under the hands of ex-leaders of the mobilized Generation of 68 , who had been some of civil society's most vigorous contestants a decade earlier.40

To claim that Mexico's democratic potential was greatest in the middle years is not to say that it was ever fully achieved. After all, we are still talking about a system of one-party rule; and serious authoritarian abuses were perpetrated during the 1950s and 1960s, mostly against the nation's independent labor and regional opposition movements but also against student and guerrilla movements. As noted earlier, the ruling party's main objective even during those years was to squelch external contestation and channel it into the party - actions which could often, and did, result in direct repression (as in the railroad worker conflict of the 1950s). But relatively speaking, this middle period - and within it, the administration of Luis Echeverría-held considerable scope for open contestation, participation, and accommodation in both the party and civil society.

Of course, the kind of democracy toward which Mexico seemed to be moving from the 1940s up through the early 1970s would not have satisfied Dahl's definition, for the PRI was still the central locus for participation and contestation, even when independent preferences in society were tolerated. The official party's commitment to electoral hegemony, moreover, meant that pressures either to incorporate or to disable external and independent opposition were always present. Therefore, it may be more accurate to say that during this middle period Mexico exhibited a precarious and temporary equilibrium between party incorporation and societal independence that may have been the best one could hope for in a noncompetitive party system.

These conclusions about the historical variations in Mexico's democratic potential provide a way of reconciling the contradictory readings of the Mexican regime in the literature. As already noted, during the 1960s many scholars saw the Mexican political system as relatively pluralistic and a near but imperfect democracy; yet by the mid- to late-seventies the academic language of pluralism was eclipsed by that of authoritarianism. This change is partly due to the violent state actions of 1968 and the armed conflict of the early

40 For a discussion of the ways in which the Generation of 68 -including those involved in Maoist and other left-proletarian movements-were recycled through the government and civil society, see Hernández (1990) and Moguel (1994). We would like to thank an anonymous reviewer for calling our attention to these sources. 
1970s. But in fact, the repression of dissidents was not new in 1968, and in the two periods before and after 1968 the same strategy of offering party-based structures for contestation and participation to opposing social forces was implemented. What was different by the late 1970 s and thereafter, then, was the institutional scope of these reforms and the character and location of the boundary line separating party structures from civil society. After the democratic openings and greater participatory inclusion of the Echeverría years, when contestion, participation, and accommodation in both society and the state reached a precariously balanced peak, democracy could advance no further without unbalancing this equilibrium and therefore undermining the basic logic of one-party rule.

All this suggests that assessments about Mexican democracy are themselves historically specific because the conditions on the ground keep changing. To draw any general conclusion about Mexico's democratic character or potential, we must understand who is contesting, participating, and responding; what historical sequencing this process follows; and how it may unfold differently in societal and party domains.

\section{Democratic Transition?}

What are Mexico's democratic prospects today and in the near future? Since the perilous transition from the Salinas to the Zedillo administration, societal contestation has increased but can no longer be accommodated or reincorporated into the official channels of the party-state. There are several reasons for this. First, the current fiscal and economic crises set strict budgetary limits on accommodation, especially in a country where most (64 of 90 million) live in poverty. Second, the party's structures cannot be reformed to be any more politically inclusive, either formally or substantively, given that party sectors are already quite widely drawn and that much current contestation is waged at the extremes of the political spectrum under the cover of violence. ${ }^{41}$ Third, the legitimacy of the regime, and therefore the likely loyalty of voters (keeping in mind that overt electoral fraud is now overly risky ${ }^{42}$ ), depends both on remembrances of how the regime has responded to past demands and on expectations for the future. After fifteen years of unfulfilled promises and of policies which have brought working-class and white-collar sectors closer to poverty, the PRI has lost the popular legitimacy it had accumulated through decades of responses to grassroots demands.

In short, the PRI is no longer a machine party capable of delivering the votes. Nor has it acquired the minimum credentials of a democratically repre-

41 We are thinking here not only of Chiapas or Guerrero but also of the growing violence in everyday political and social life, which poses a challenge to juridically legitimate ways of doing politics.

42 Since the 1994 presidential and legislative elections, a mechanism of national and foreign observers has been set up, and the Federal Electoral Institute is no longer under the full control of the state as in the past. 
sentative party. The cycles of participation, contestation, and accommodation that had periodically reestablished its legitimacy and renewed loyalties from members and other citizens have finally been broken. As a result, Mexico may finally be free from the dynamic that had sustained its noncompetitive, oneparty system and that since the 1970s had drawn it further away from-rather than closer to-fulfilling its democratic potential.

But, with the cycle broken and the official party hitting rock bottom in 1995 in terms of legitimacy and democratic potential, is a transition to full democracy now imminent? It is very hard to speculate about the future, precisely because we are seeing an entirely new political game in Mexico for the first time since the Revolution. One change is highly important: With the official party unable to count on an effective or legitimate political machine, there is now space for other parties to flourish, despite rearguard electoral violence by PRI "militants" in some regions. So, Mexico may finally have entered the era of competitive party politics. To Dahl and his followers, that may indicate that democracy has finally arrived. But if accommodation should also be seen as a key indicator of democracy, as we claim, that conclusion is too simple. Even with free and competitive elections, it is highly unlikely that Mexicans will change their views overnight on what they expect the state to provide. Nor will they remain loyal supporters of parties that have shunned accommodations in the past or are unable to offer any now. The PRI's electoral defeat and the end of one-party rule, in short, cannot guarantee that open contestation over policy will not persist or that accommodation will be forthcoming. Though in some general sense the end of one-party rule can only be good for democracy, it does not necessarily bode well for political stability. In the current climate of violence, any party that does come to power may then fall back on authoritarian measures to maintain social order.

For Mexico, then, current and future possibilities for participation, contestation, and accommodation may still be a better indicator of democratic potential than the sheer presence or absence of competitive elections. The PRI's recent shift to the right and the abandonment of social justice concerns by technocrats weaned on the calculus of comparative advantages has narrowed party participation to those policy makers eager to balance the budget but unwilling to provide more than a minimum of accommodation. In short, the democratic transition presently touted by the Zedillo administration lacks a basic element of democracy, namely, the capacity to accommodate its citizens' demands; and substantive political participation is also highly circumscribed. This is not merely the PRI's problem, since none of the parties likely to win in a free and competitive election could perhaps do otherwise, given the current economic and political climate. The neo-liberal platform of the ever more popular right-wing opposition, Partido Acción Nacional (PAN), is essentially the same. The weakest contender-the left-wing Partido de la Revolu- 
ción Democrática (PRD) — is the only party prepared to raise issues of social justice and accommodation of citizen demands.

Mexico's future, then, may just depend on how well the Zedillo government contributes to the establishment of new rules for participation and contestation that can persuade contesting forces to forego immediate accommodation, rules that other parties could also benefit from if they come to power. The success of such a strategy depends on whether the present government can keep discontents divided (rather than incorporate them, as in the past) and on whether economic conditions ease up enough to diminish the contestants' demands for accommodation while political leaders negotiate the redesign of rules. If their efforts are successful, Mexico will have entered another historical phase and taken a giant step with respect to its one-party past.

But a celebration may be premature. The pessimistic view is that any feasible democratic experiment is likely to leave out accommodation. For Mexico, as well as for many other post-transition democracies, newly devised arrangements for participation and contestation have to be appealing enough to inspire a willingness to postpone accommodation, especially on the part of the impoverished majority. Yet since participation and contestation normally generate demands for accommodation, this is highly unlikely. Mexico, like other newly democratic countries around the globe, could end up being stalled in incomplete transition. Contestation and participation would be circumscribed in the name of governability, and freedom of expression limited in order to stem accommodation demands. A worst-case scenario, perhaps, but not an impossible one for Mexico.

\section{REFERENCES}

Aguilar Zinser, Adolfo. 1989. "Desconcertante aceptación del nuevo presidencialismo." Excelsior (July 23).

Aldrete Haas, José Antonio. 1991. La desconstrucción del Estado Mexicano: políticas de vivienda, 1917-1988. México: Nueva Imagen.

Archivo General de la Nación. 1936. Galería de presidentes (Cárdenas). Expediente 437.1/512.

Brachet-Márquez, Viviane. 1994a. The Dynamics of Domination: State, Class and Social Reform in Mexico (1910-1990). Pittsburgh: Pittsburgh University Press.

_. 1994b. "Los movimientos sociales 'viejos' y 'nuevos', las movilizaciones estudiantiles y populares en una perspectiva comparativa," in Transformaciones sociales y acciones colectivas: América Latina en el contexto internacional de los noventas, Centro de Estudios Sociológicos, ed. México D.F.: El Colegio de México.

Brachet-Márquez, Viviane; and Margaret Sherraden. 1994. "Political Change and the Welfare State: The Case of Health and Food Policies in Mexico (1970-93)." World Development, 22:9, 1295-1312.

Calegione, John; Doris Francis; and Daniel Nugent, eds. 1992. Workers' Expressions: Beyond Accommodation and Resistance. Albany: State University of New York. 
Carr, Barry; and Ricardo Anzaldua Montoya, eds. 1986. The Mexican Left, the Popular Movements and the Politics of Austerity 1982-85. La Jolla: Center for U.S.Mexican Studies, University of California, San Diego.

Centeno, Miguel, 1994. Democracy Within Reason. University Park: Pennsylvania State University Press.

Cline, Howard. 1962. Mexico: Revolution to Evolution 1940-1960. New York: Oxford University Press.

Collier, Ruth Berins. 1982. "Popular Sector Incorporation and Political Supremacy: Regime Evolution in Brazil and Mexico," 57-109, in Sylvia A. Hewlett and Richard S. Weinert, eds., Brazil and Mexico. Philadelphia: Institute for the Study of Human Issues.

Cook, María Elena; Kevin Middlebrook; and Juan Molinar Horcasitas, eds. 1994. The Politics of Economic Restructuring: State-Society Relations and Regime Change in Mexico. U.S.-Mexico Contemporary Perspectives Series, 7, Center for U.S.Mexican Studies, University of California, San Diego.

Cornelius, Wayne. 1975. Politics and the Migrant Poor in Mexico City. Stanford: Stanford University Press.

- 1996. Mexican Politics in Transition. The Breakdown of a One-PartyDominant Regime. La Jolla: Center for U.S.-Mexican Studies, University of California, San Diego.

Cornelius, Wayne; Ann Craig; and Jonathan Fox. 1994. Transforming State-Society Relations in Mexico. The National Solidarity Strategy. La Jolla: Center for U.S.Mexican Studies, University of California, San Diego.

Cornelius, Wayne; Judith Gentleman; and Peter H. Smith, eds. 1989. Mexico's Alternative Political Futures, Monograph Series no. 30. La Jolla: Center for U.S.-Mexican Studies, University of California, San Diego.

Cosio Villegas, Daniel. 1973. El sistema político mexicano. Mexico: Joaquin Mortiz.

Cumberland, Charles. 1968. The Struggle for Modernity. Oxford: Oxford University Press.

Cumings, Bruce. 1989. "The Abortive Abertura: South Korea in the Light of Latin American Experience." New Left Review, 173 (January-February), 5-32.

Dahl, Robert. 1971. Polyarchy: Participation and Opposition. New Haven: Yale University Press.

Davis, Diane E. 1997. "New Social Movements, Old Party Structures: The Discursive and Organizational Transformation of Party Politics in Mexico and Brazil," in The Politics of Social Change and Economic Restructuring in Latin America, Roberto Patricio Korzeniewicz and William P. Smith, eds. Boulder: Lynne Rienner Publishers.

- 1995. "Uncommon Democracy in Mexico: Middle Classes and the Military in the Consolidation of One-party Rule, 1936-1946," 161-89, in Herrick Chapman and George Reid Andrews, ed., The Social Construction of Democracy, 1880-1990. London: Macmillan Press.

—. 1994a. "Mexico's New Politics: Changing Positions on Free Trade." World Policy Journal, 9:4, 655-72.

_. 1994b. Urban Leviathan: Mexico City in the Twentieth Century. Philadelphia: Temple University Press.

. 1990. "Urban Social Movements, Intra-state Conflicts over Urban Policy, and Political Change in Contemporary Mexico," in Michael Peter Smith, ed., Breaking Chains: Social Movements and Collectve Action. Los Angeles and London: Sage Publications.

- 1989. "Divided over Democracy: The Embeddedness of State and Class Conflicts in Contemporary Mexico." Politics and Society, 17:3, 247-80. 
Di Palma, Guiseppe. 1990. To Craft Democracies. An Essay on Democratic Transitions. Berkeley: University of California Press.

Diamond, Larry; Juan Linz; and Seymour Martin Lipset, eds. 1989. Democracy in Developing Countries, vol. 4, Latin America. Boulder, CO: Lynne Rienner Publishers.

Dresser, Denise. 1994. "Embellishment, Empowerment, or Euthanasia of the PRI? Neoliberalism and Party Reform in Mexico," 125-48, in The Politics of Economic Restructuring: State-Society Relations and Regime Change in Mexico, Maria Lorena Cook, Kevin J. Middlebrook, and Juan Molinar Horcasitas, eds. San Diego: Center for Studies of U.S.-Mexican Studies, University of California at San Diego. 1991. Neopopulist Solutions to Neoliberal Problems: Mexico's National Solidarity Program. La Jolla: Center for U.S.-Mexican Studies, University of California, San Diego.

Eckstein, Susan. 1977. The Poverty of Revolution. Princeton: Princeton University Press.

EZLN. 1994. Documentos y comunicados. 1 de enero 1994/ 8 de agosto 1994. Mexico: Ediciones Era.

Fagen, Richard; and William S. Tuohy. 1974. Politics and Privilege in a Mexican City. Stanford: University of California Press.

Foweraker, Joe. 1990. "Popular Movements and Political Change in Mexico," in Рориlar Movements and Political Change in Mexico, Joe Foweraker and Ann L. Craig, eds. Boulder: Lynne Rienner Publishers.

Fox, Jonathan. 1992. The Politics of Food in Mexico: State Power and Social Mobilization. Ithaca: Cornell University Press.

1994 "The Difficult Transition from Clientelism to Citizenship: Lessons from Mexico." World Politics, 46 (January), 151-84.

González Casanova, Pablo. 1986. El estado y los partidos políticos, 3rd ed. Mexico: Ediciones Era.

- 1970. Democracy in Mexico. New York: Oxford University Press.

Haber, Paul L. 1994a. "The Art and Implications of Political Restructuring in Mexico: The Case of Urban Popular Movements," 277-306, in The Politics of Economic Restructuring: State-Society Relations and Regime Change in Mexico, Maria Lorena Cook, Kevin J. Middlebrook, and Juan Molinar Horcasitas, eds. San Diego: Center for Studies of U.S.-Mexican Studies, University of California at San Diego.

. 1994b. "Political Change in Durango," in Wayne Cornelius, Ann Craig, and Jonathan Fox, eds., Transforming State-Society Relations in Mexico: The National Solidarity Strategy. La Jolla: Center for U.S.-Mexican Studies, University of California, San Diego.

Hakim, Peter; and Abraham Lowenthal. 1991. "Latin America's Fragile Democracies," Journal of Democracy, 2:3, 16-29.

Hamilton, Nora. 1982. The Limits of State Autonomy: Postrevolutionary Mexico. Princeton: Princeton University Press.

Hellman, Judith Adler. 1983. Mexico in Crisis, 2nd ed. New York: Holmes and Meier. Hernández, Luis. 1990. La Unión de Ejidos Lázaro Cárdenas: cuadernos desarrollo de base 1. Mexico City: Interamerican Foundation.

Hernández, Ricardo. 1987. La Coordinadora Nacional del Movimiento Urbano Popular (CONAMUP): U historia 1980-1986. México: Equipo Pueblo.

Huntington Samuel. 1968. Political Order in Changing Societies. New Haven: Yale University Press.

Kaufman Susan. 1973. "Decision Making in an Authoritarian Regime: Theoretical Implications from a Case Study." World Politics, 26:1, 28-54. 
1975. The Mexican Profit-Sharing Decision: Politics in an Authoritarian Regime. Princeton: Princeton University Press.

Lipset, Seymour Martin. 1960. Political Man. The Social Bases of Politics. Garden City: Anchor Books.

Lieuwen, Edwin. 1968. Mexican Militarism: The Political Rise and Fall of the Revolutionary Army, 1910-1940. Albuquerque: University of New Mexico Press.

Loaeza, Soledad. 1988. Las clases medias y la política en México. Mexico: El Colegio de Mexico.

Loyo, Aurora. 1990. "La Confederación Proletaria Nacional: Un primer intento de quebrar la hegemonía de la CTM," in Entre guerra y estabilidad politica: el México de los 40, Rafael Loyo, ed. Mexico: Grijalbo.

Lozoya, Jorge Alberto. 1976. El ejército mexicano. Colección Jornada. México: El Colegio de México.

Malloy, James; and Mitchell A. Seligson, ed. 1987. Authoritarians and Democrats: Regime Transition in Latin America. Pittsburgh: Pittsburgh University Press.

Moguel, Julio. 1994. "The Mexican Left and the Social Program of Salinismo," in Wayne Cornelius, Ann Craig, and Jonathan Fox, eds., Transforming State-Society Relations in Mexico: The National Solidarity Strategy. La Jolla: Center for U.S.Mexican Studies, University of California, San Diego.

Moguel, Julio; Carlota Botey; Luis Hernández. 1992. Autonomía y nuevos sujetos sociales en el desarrollo rural. Mexico: Siglo XXI.

Molinar Horcasitas, Juan; and J. A. Weldon. 1994. "Electoral consequences of National Solidarity," in Wayne Cornelius, Ann Craig, and Jonathan Fox, eds., Transforming State-society Relations, U.S.-Mexico Contemporary Perspectives Series No 6. La Jolla: Center for U.S.-Mexican Studies, University of California, San Diego.

Moore, Barrington, Jr. 1966. Social Origins of Dictatorship and Democracy: Lord and Peasant in the Making of the Modern World. Boston: Beacon Press.

Needler, Martin. 1971. Politics and Society in Mexico. Albuquerque: University of New Mexico Press.

Nugent, Daniel; and Gilbert Joseph, eds. 1994. Everyday Forms of State Formation: Revolution and the Negotiation of Rule in Modern Mexico. Durham: Duke University Press.

O’Donnell, Guillermo. 1994. "Delegative Democracy." Journal of Democracy, 5:1, 55-69.

O'Donnell, Guillermo; Philip Schmitter; and Laurence Whitehead, eds. 1986. Transitions from Authoritarian Rule: Latin America. Baltimore, MD: Johns Hopkins University Press.

Padgett, Vincent. 1966. The Mexican Political System. Boston: Houghton Mifflin Co.

Pécaut, Daniel; and Marie-France Prévôt-Shapira. 1992. "La Recherche d'une Nouvelle Légitimation: Le Programme National de Solidarité.” Problèmes d' Amérique Latine, Trimestre no. 5 Nouvelle Série, (April-June), 91-104.

Peschard, Jacqueline. 1988. "Las Elecciones en el Distrito Federal entre 1964 y 1985." Estudios Sociológicos, 6:16.

Purcell, Susan Kaufman; and John F. H. Purcell. 1976. "Machine Politics and SocioEconomic Change," in James Wilkie, Michael Meyer, and Edna Monzon de Wilkie, eds., Contemporary Mexico. Berkeley: University of California Press.

- 1980. "State and Society in Mexico: Must a Stable Polity be Institutionalized?" World Politics, 32:2, 194-227.

Reyna, José Luis. 1974. Control político, estabilidad y desarrollo en México, Cuadernos del CES No 3. Mexico: El Colegio de México. 
Reyna, José Luis; and Richard Weinert, eds. 1977. Authoritarianism in Mexico. Philadelphia: Institute for the Study of Human Issues.

Rivero, Martha. 1990. "La Política Económica durante la Guerra," in Entre guerra y la estabilidad política: el México de los 40, Rafael Loyola, ed. Mexico: Grijalbo.

Roxborough, Ian. 1984. Unions and Politics in Mexico: The Case of the Automobile Industry. New York: Cambridge University Press.

Rueschemeyer, Dietrich; Evelyn Huber Stephens; and John D. Stevens. 1992. Capitalist Development and Democracy. Chicago: University of Chicago Press.

Scott, Robert E. 1964. Mexican Government in Transition. Urbana: University of Illinois Press.

Smith, Peter H. 1991. "Mexico since 1946: Dynamics of an Authoritarian Regime," 321-97, in Leslie Bethell, ed., Mexico since Independence. Cambridge: Cambridge University Press.

Stevens, Evelyn. 1974. Protest and Response in Mexico. Cambridge: MIT Press.

Story, Dale. 1986. Industry, the State, and Public Policy in Mexico. Austin: University of Texas Press.

Teichman, Judith A. 1988. Policymaking in Mexico: From Boom to Crisis. Boston: Allen and Unwin.

Trejo Delarbre, Raúl. 1986. "The Mexican Labor Movement: 1917-1975,” 177-205, in Nora Hamilton and Timothy Harding, eds., Modern Mexico: State, Economy and Social Conflict. Beverly Hills: Sage Publications. 